\title{
Effects of Rifampicin, Streptolydigin and Actinomycin D on the Replication of Col E1 Plasmid DNA in Escherichia coli
}

\author{
Don B. Clewell and Bruce G. EvenchiK \\ Departments of Oral Biology and Microbiology \\ Schools of Dentistry and Medicine \\ The University of Michigan \\ Ann Arbor, Mich. 48104, U.S.A.
}

(Received 23 October 1972, and in revised form 1 January 1973)

\begin{abstract}
We recently reported (Clewell et al., 1972) on an inhibitory effect of rifampicin on Col El plasmid replication. The present study represents a further characterization of this phenomenon as well as a study of the effects of two other known inhibitors of RNA synthesis, streptolydigin and actinomycin D.

During treatment of cells with chloramphenicol the colicinogenic factor $\mathbf{E}_{1}$ (Col E1) continues to replicate for more than ten hours. During this time 4 to $5 \mathrm{~S}$ RNA is also synthesized. When varying concentrations of rifampicin were included during chloramphenicol treatment, inhibition of plasmid DNA synthesis correlated very closely with inhibition of cellular RNA synthesis. Similar experiments testing the effects of streptolydigin and actinomycin $\mathbf{D}$ (during chloramphenicol treatment) showed that cellular RNA synthesis was at least 100 times more sensitive to these drugs than was plasmid DNA synthesis.

When actively growing cells (i.e. cells not treated with chloramphenicol) were treated with a high concentration of rifampicin $(250 \mu \mathrm{g} / \mathrm{ml})$, chromosomal DNA synthesis continued to an extent representing about a $50 \%$ increase in DNA, while plasmid DNA synthesis appeared to stop abruptly.
\end{abstract}

\section{Introduction}

The colicinogenic factor E1, in Escherichia coli, has several features which make it an attractive system for studying DNA replication. First, it is a relatively small circular DNA molecule (mol. wt $4 \cdot 2 \times 10^{6}$ ), present to the extent of 20 to 30 copies per cell, and it can be isolated by simple and rapid procedures (Bazaral \& Helinski, 1968; Clewell \& Helinski, 1972). Second, it has been found to replicate semiconservatively in the presence of high levels of chloramphenicol, long after chromosomal DNA replication has ceased (Clewell \& Helinski, 1972; Clewell, 1972). During this time the average rate of plasmid DNA synthesis increases until, after two to four hours, a maximum rate is achieved corresponding to about eight times the normal average rate that would be required to double the amount of plasmid DNA per cell in one generation (Clewell, 1972). Synthesis continues for 10 to 15 hours with a net accumulation of about 3000 copies of Col EI DNA per cell.

We are currently making use of this system to examine the effects of a number of antibiotics on DNA replication, and have reported recently on a potent inhibitory effect of rifampicin (Clewell et al., 1972). Since rifampicin is a specific inhibitor of 
DNA-dependent RNA polymerase, and since plasmid replication is rifampicinresistant in strains containing rifampicin-resistant RNA polymerase, we suggested that at least the beta subunit of the polymerase (which is the part that interacts with rifampicin) may be in some way closely involved in DNA replication.

In this paper we report a more detailed examination of the effects of rifampicin on Col El DNA replication, both in chloramphenicol-treated cells and in actively growing cells. Studies of the inhibitory effects of rifampicin, streptolydigin and actinomycin D on plasmid DNA synthesis and cellular RNA synthesis during chloramphenicol treatment reveal that RNA and DNA syntheses are equally sensitive to rifampicin, whereas RNA synthesis is at least 100 times more sensitive than DNA synthesis to streptolydigin and actinomycin $\mathrm{D}$.

\section{Materials and Methods}

\section{(a) Bacterial strains and media}

E. coli K12 strain CR34 (Col F1) (anxotrophic for Thr, Leu, vitamin Bl and Thy) (Okada et al., 1960) and a streptolydigin-sensitive derivative (Slyd-1) were used in this study. Each strain harbors the Col El plasmid DNA, which was originally transferred by conjugation from $E$. coli K30. An M9-glucose-Casamino acids (Difeo) medium containing thymine $(5 \mu \mathrm{g} / \mathrm{ml})$ and vitamin Bl $(2.5 \mu \mathrm{g} / \mathrm{ml}$ ) (Clewell, 1972) was used for all of the experiments in this work except the $\left[{ }^{3} \mathrm{H}\right]$ leucine-labeling experiment. In the latter, the Casamino acids were replaced by separate addition of leucine $(25 \mu \mathrm{g} / \mathrm{ml})$ and each of the other required amino acids $(50 \mu \mathrm{g} / \mathrm{ml})$. Cell growth was at $37^{\circ} \mathrm{C}$ and turbidity was monitored using a Klett-Summerson colorimeter.

Slyd-1, the streptolydigin-sensitive mutant, was derived as follows: CR34 (Col E1) cells were treated for $15 \mathrm{~min}$ with nitrosoguanidine $(30 \mu \mathrm{g} / \mathrm{ml})$ in Penassay broth (Difeo) at $37^{\circ} \mathrm{C}$. Cells were pelleted and resuspended in Penassay broth, allowed to segregate (overnight growth) and then treated for $6 \mathrm{~h}$ with penicillin $\mathrm{G}(2000 \mathrm{units} / \mathrm{ml})$ and streptolydigin $(30 \mu \mathrm{g} / \mathrm{ml})$. Cells were plated and colonies were tested for streptolydigin sensitivity on Penassay broth-agar containing $50 \mu \mathrm{g}$ streptolydigin $/ \mathrm{ml}$. Streptolydigin sensitivity was observed in 2 out of 40 colonies picked.

\section{(b) Materials}

Reagents and sources were as follows: Brij-58 from Emulsion Engineering Inc.; sodium deoxycholato from Difco Laboratorics; sodium dodocyl sulfate from Fisher Sciontific; egg white lysozyme, pronase, ethidium bromide, penicillin G, rifampicin (rifampin) (Lepetit), tetracycline and streptomycin sulfate from Calbiochem; chloramphenicol from Parke, Davis \& Co.; actinomyein D from Merck, Sharp \& Dohme; streptolydigin was a gift from the Upjohn Co.; puromycin from Nutritional Biochemical Corp.; CsCl (optical grade) from Schwartz Bioresearch, Inc.; [ $\left.m e t h y l .{ }^{3} \mathrm{H}\right]$ thymine $(11.7 \mathrm{Ci} / \mathrm{mmol}),\left[{ }^{14} \mathrm{C}\right]$ thymine $(55 \cdot 8 \mathrm{mCi} / \mathrm{mmol}),\left[5-{ }^{3} \mathrm{H}\right]$ uridine $(26 \cdot 0 \mathrm{Ci} / \mathrm{mmol})$ and $\mathrm{L}-\left[4,5-{ }^{3} \mathrm{H}\right] l$ leucine $(5 \cdot 0 \mathrm{Ci} / \mathrm{mmol})$ from New England Nuclear.

\section{(c) Preparation of lysates}

The lysing procodure has boon doseribed in detail proviously (Clewoll \& Helinsli, $1969,1970)$. It involves the lysis of EDTA-lysozyme spheroplasts with a detergent mixture of Brij-58 and sodium deoxycholate. A 48,000 $\mathrm{g}$ centrifugation (for $25 \mathrm{~min}$ ) of the crude lysate pellets a. major portion of the chromosomal DNA, leaving plasmid DNA in the supernatant. This supernatant is referred to as cleared lysate. Crude lysates and cleared lysates can be frozen $\left(-70^{\circ} \mathrm{C}\right)$ until ready for further use. The lysis procedure used for RNA extraction is described below.

\section{(d) Ultracentrifugation procedures}

Dye-buoyant density equilibrium centrifugation and sucrose density gradient centrifugation were done as described previously (Clewell \& Helinski, 1970; Clewell, 1972; 
Clewell et al, 1972). When RNA was analyzed, the sucrose gradients contained $0.15 \mathrm{~m}$ $\mathrm{NaCl}, 0.005 \mathrm{M}$-disodium EDTA and $0.03 \mathrm{M}$-Tris, $\mathrm{pH} 8.0$.

\section{(e) Extraction of $R N A$}

Cells labeled with $\left[{ }^{3} \mathrm{H}\right]$ uridine were harvested and resuspended in $1 \mathrm{ml}$ of $25 \%$ sucrose $(0.05$ м-Tris, $\mathrm{pH} 8.0)$. A $0.2-\mathrm{ml}$ portion of lysozyme $(5 \mathrm{mg} / \mathrm{ml}$ in $0.05 \mathrm{M}$-Tris, $\mathrm{pH} 8.0)$ was added and, after $5 \mathrm{~min}$ at $25^{\circ} \mathrm{C}, 0.2 \mathrm{ml}$ of $0.007 \mathrm{M}$-disodium EDTA $(\mathrm{pH} 8.0)$ was added. Upon incubation for another $5 \mathrm{~min}\left(25^{\circ} \mathrm{C}\right), 1 \cdot 6 \mathrm{ml}$ of $2.0 \%$ sodium dodecyl sulfate (in $0.05 \mathrm{M}$-Tris ( $\mathrm{pH} \mathrm{8.0)}, 0.03 \mathrm{M}-\mathrm{MgCl}_{2}$ ) was added. An equal volume of a phenol/chloroform mixture (2:1), saturated with Tris/EDTA/NaCl buffer $(0.03 \mathrm{~m}$-Tris, $0.005 \mathrm{~m}$-disodium EDTA ( $\mathrm{pH} 8 \cdot 0$ ), $0.05 \mathrm{M}-\mathrm{NaCl}$ ), was added to the lysate and mixed vigorously with a Vortex. The aqueous phase was removed (after low-speed centrifugation) and the procedure repeated. The aqueous phase was then adjusted to 0.I $\mathrm{M}-\mathrm{NaCl}$, after which the RNA was precipitated with 2 volumes of $95 \%$ ethanol. The precipitate was pelleted and redissolved in $1.0 \mathrm{ml}$ of Tris/ $\mathrm{NaCl} / \mathrm{EDTA}$ buffer.

\section{(f) Counting of radioisotopes}

Samples were prepered and counted as described previously (Clewell \& Helinski, 1970) in a Beckman LS250 liquid scintillation system.

\section{Results}

\section{(a) Comparison of cellular RNA synthesis with plasmid DNA synthesis during antibiotic treatment}

While previously we showed (Clewell et al., 1972) that rifampicin inhibited Col El replication as well as cellular RNA synthesis in chloramphenicol-treated cells, the exact drug sensitivity of these two processes was not quantitated. The following experiments were designed to determine the levels of sensitivity to rifampicin as well as to two other known inhibitors of RNA synthesis.

Cam $\dagger$ was added to a culture of CR34 (Col El) cells that had been growing for several generations in log phase. After 3.5 hours, the culture was divided into 4-ml portions, to each of which was added a specified quantity of rifampicin. After 30 minutes a mixture of $\left[{ }^{3} \mathrm{H}\right]$ uridine and $\left[{ }^{14} \mathrm{C}\right]$ thymine was added to each portion; after 15 minutes of labeling, $\mathrm{NaN}_{3}$ was added and the cells were plunged into an ice bath. The cells were lysed and samples were removed to determine the amount of radioactivity incorporated into acid-precipitable material. The results are shown in Figure 1. A correlation between the incorporation of $\left[{ }^{3} \mathrm{H}\right]$ uridine and $\left[{ }^{14} \mathrm{C}\right]$ thymine at different concentrations of rifampicin is readily apparent. The concentration of rifampicin required for $50 \%$ inhibition was about $0.1 \mu \mathrm{g} / \mathrm{ml}\left(1.2 \times 10^{-7} \mathrm{M}\right)$ in each case. On the basis of ${ }^{14} \mathrm{C}$ counts (DNA) in the crude lysates, a "maximum" inhibition of about $75 \%$ is evident. The remaining $25 \%$ represents rifampicin-resistant DNA synthesis. This DNA is not of a covalently closed nature, as is apparent when portions of lysates were analyzed in dye-buoyant density gradients (Clewell et al., 1972) (Fig. 2). Covalently closed circular Col El DNA bands, under these conditions, at a higher density than linear or nicked circular DNA (Radloff et al., 1967). It is evident that the synthesis of the DNA found in the less dense band is unaffected by rifampicin, whereas closed circular DNA is not made at $10 \mu \mathrm{g}$ rifampicin $/ \mathrm{ml}$. In separate experiments, sucrose density gradient analyses of material in the less dense band indicate that about $80 \%$ of this DNA is chromosomal, the remainder being rifampicin-sensitive, 


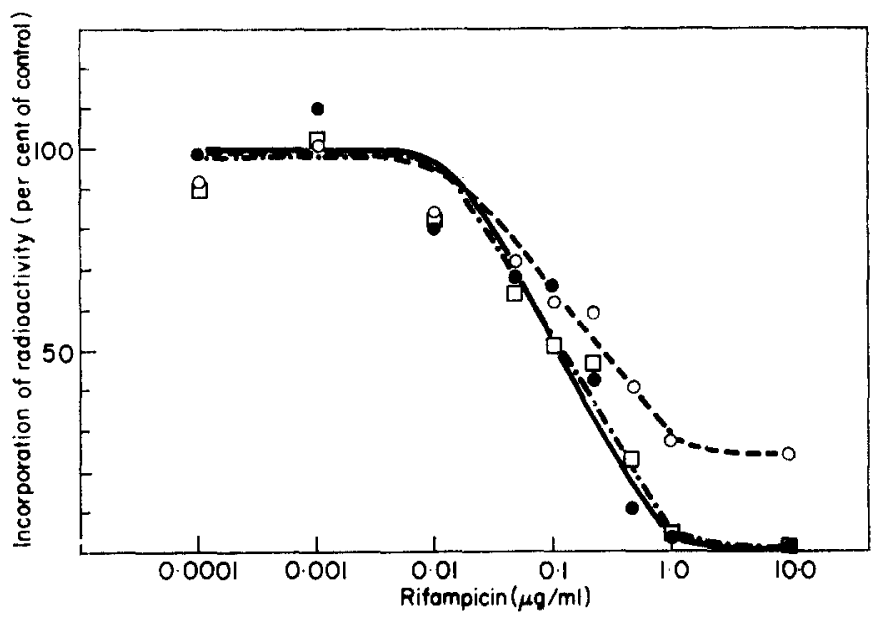

Fic. 1. Comparison of the effect of various concentrations of rifampicin on plasmid DNA synthesis and cellular RNA synthesis during treatment with Cam. E. coli CR34 (Col E1) cells $(47 \mathrm{ml})$ were grown for several generations in log phase to a point representing about $3 \times 10^{8}$ cells $/ \mathrm{ml}$. Cam $(150 \mu \mathrm{g} / \mathrm{ml})$ was added and, after $3.5 \mathrm{~h}$, the culture was divided into 4-ml portions. To each was added $0.4 \mathrm{ml}$ of rifampicin (various concentrations) in water and, after $30 \mathrm{~min}$, $0 \cdot 3-\mathrm{ml}$ portions of an aqueous solution containing $20 \mu \mathrm{Ci}(0 \cdot 19 \mu \mathrm{g})\left[{ }^{3} \mathrm{H}\right]$ uridine and $10 \mu \mathrm{Ci}(22 \mu \mathrm{g})$ $\left.{ }^{14} \mathrm{C}\right]$ thymine. After a 15 -min labeling period, $\mathrm{NaN}_{3}$ was added (to $0.05 \mathrm{M}$ ) and the cells were plunged into an ice bath. Cells were harvested, lysed (by the Brij-deoxycholate procedure) and $0.1-\mathrm{ml}$ samples (in duplicate) were used to determine the level of ${ }^{14} \mathrm{C}$ and ${ }^{3} \mathrm{H}$ present as trichloroacetic acid-precipitable material. The results (averages of duplicate determinations) are shown in the Figure. The $\left[{ }^{14} \mathrm{C}\right]$ thymine incorporation is plotted both as reflecting total cts/min in the crude lysate and after correction for residual chromosomal DNA synthesis by subtracting the cts/min obtained for the $10 \mu \mathrm{g} / \mathrm{ml}$ (rifampicin) point from each of the other points. The level of radioactivity in the control sample was $129,266 \mathrm{cts} / \mathrm{min}$ of ${ }^{3} \mathrm{H}$ and $982 \mathrm{cts} / \mathrm{min}$ of ${ }^{14} \mathrm{C}$. (O) Incorporated $\left[{ }^{3} \mathrm{H}\right] \mathrm{uri}$ dine; (O) incorporated $\left[{ }^{14} \mathrm{C}\right]$ thymine; $(\square)$ incorporated $\left[{ }^{14} \mathrm{C}\right]$ thymine (corrected).

non-supercoiled Col E1 DNA (representing less than $5 \%$ of the total plasmid DNA in the lysate). When the radioactivity present in the "light" band is subtracted from the total ${ }^{14} \mathrm{C}$ counts in each crude lysate, a value is obtained which should correspond closely to covalently closed plasmid DNA. Such corrected values are plotted separately in Figure 1 and generate a curve which is superimposed on that representing incorporated $\left[{ }^{3} \mathrm{H}\right]$ uridine.

Using our streptolydigin-sensitive strain, Slyd-1, we did an experiment similar to the above except that the effect of streptolydigin was analyzed. The results shown in Figure 3(a) indicate that, unlike rifampicin, more than 100 times as much streptolydigin is required to inhibit DNA synthesis as is required to inhibit RNA synthesis. A streptolydigin concentration of about $0.5 \mu \mathrm{g} / \mathrm{ml}\left(8.3 \times 10^{-7} \mathrm{M}\right)$ provided $50 \%$ inhibition of cellular RNA synthesis, whereas greater than $50 \mu \mathrm{g} / \mathrm{ml}$ was necessary for a similar inhibition of DNA synthesis. Although there appears to be some selective inhibition of synthesis of DNA isolated as closed circular molecules (Fig. 3(c)), concentrations greater than $100 \mu \mathrm{g} / \mathrm{ml}$ appear also to affect synthesis of DNA found in the less dense band. It is interesting that the concentration of streptolydigin that provides $50 \%$ inhibition of cell RNA synthesis is about tenfold less than that reported for the in vitro inhibition of RNA polymerase (Cassani et al., 1970). The reason for this is not apparent but may simply reflect differences between in vivo and in vitro conditions. 


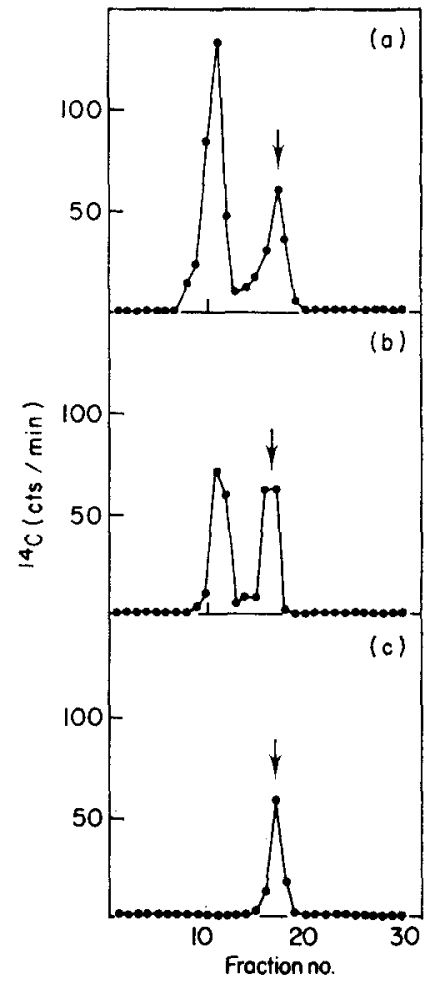

FIG. 2. Dye-buoyant density centrifugation of crude lysates of cells treated with chloramphenicol and rifampicin. The lysates $(1 \mathrm{ml})$ were centrifuged to equilibrium in $\mathrm{CsCl}$ buoyant density gradients containing ethidium bromide. Density increases from right to left: (a) control colls; (b) and (c) cells of Fig. 1 that had been treated with 0.1 and $10.0 \mu \mathrm{g}$ rifampicin/ml, respectively. The arrow represents the banding position of chromosomal DNA.

Actinomycin D was tested in a similar manner (see Fig. 3(b) and (d)) and was found to be like streptolydigin. While $0.1 \mu \mathrm{g} / \mathrm{ml}\left(8.0 \times 10^{-8} \mathrm{M}\right)$ provides about $50 \%$ inhibition of RNA synthesis, close to $10 \mu \mathrm{g} / \mathrm{ml}$ is required for a similar inhibition of DNA synthesis. As in the case of streptolydigin, dye-buoyant density analyses (Fig. 3(d)) indicate some selective inhibition of Col El DNA but not to the extent seen with rifampicin.

\section{(b) Nature of cellular $R N A$ synthesis during extensive chloramphenicol treatment}

Since the above experiments have involved measurements of cellular RNA synthesis during highly abnormal conditions (i.e. after several hours of Cam treatment), it was of interest to know more about the RNA being produced, with regard to both over-all rate of synthesis and the nature of the RNA.

Experiments involving pulse-labeling with $\left[{ }^{3} \mathrm{H}\right]$ uridine (10-min pulses) at various time points after the addition of Cam have indicated (data not shown) that CR34 (Col E1) cells synthesize RNA at a rate which, within 30 minutes, increases by $20 \%$ and remains at this level for about two hours. After four hours the rate is decreased 


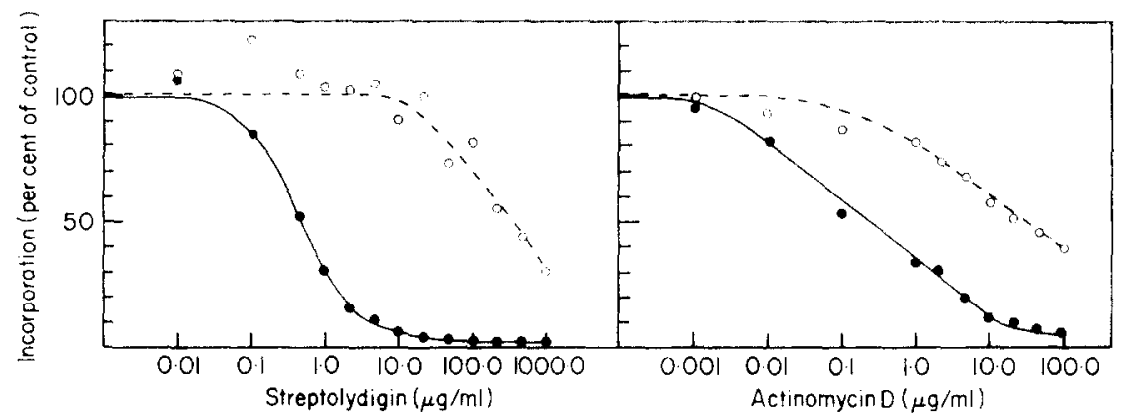

(a)

(b)

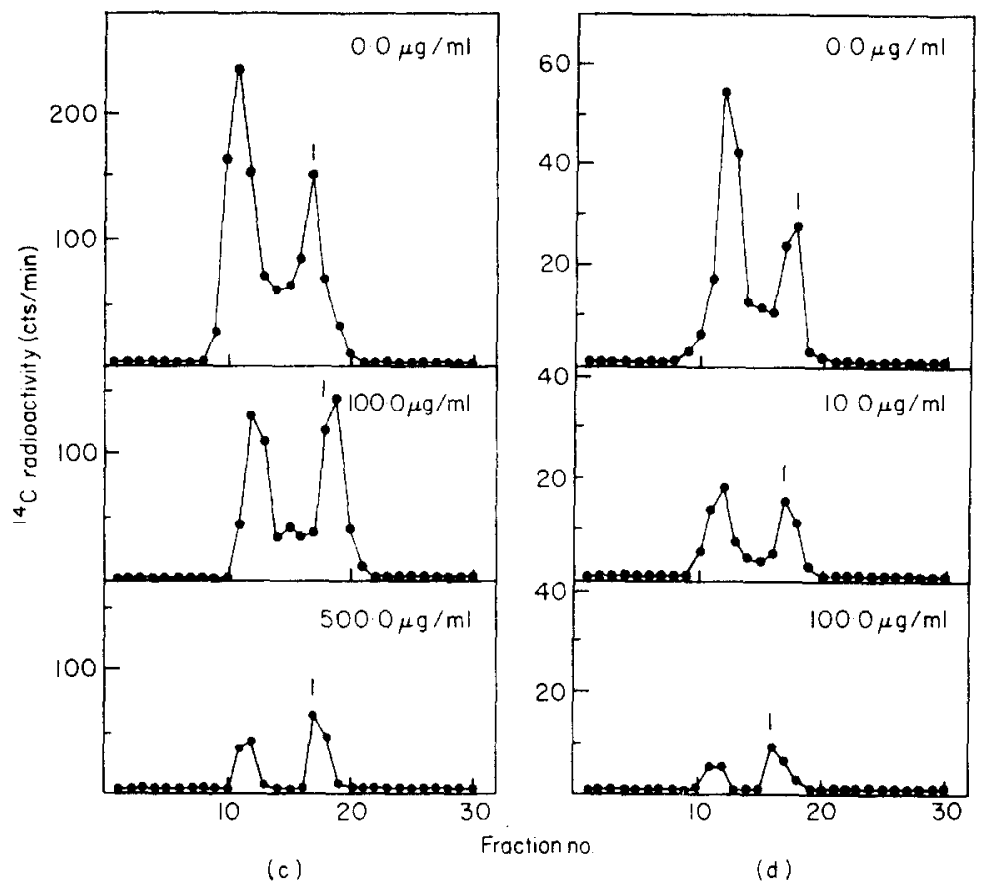

FIG. 3. Comparison of the effects of various concentrations of streptolydigin and actinomycin $D$ on plasmid DNA synthesis and cellular RNA synthesis during treatment with Cam. $E$. coli CR34 (Col El) cells were grown and treated in a manner similar to that described in the legend to Fig. 1 , except that samples $(0.1 \mathrm{ml})$ of streptolydigin or actinomycin $\mathrm{D}$ (various concentrations) dissolved in dimethyl sulfoxide were added to each 4-ml portion of Cam-treated cells. Control cells received $0.1 \mathrm{ml}$ dimethyl sulfoxide containing no drug. The streptolydigin-sensitive strain Slyd-1 was used for the streptolydigin experiment. In the experiment using actinomycin $D$, disodium EDTA was added (final conen of $0.01 \mathrm{M}$ ) $5 \mathrm{~min}$ before division of the culture into 4-ml portions. The results of determinations of ${ }^{14} \mathrm{C}$ and ${ }^{3} \mathrm{H}$ radioactivity in the crude lysates (average of duplicate (in the case of streptolydigin) or triplicate (in the case of actinomycin D) determinations on $0 \cdot 1$. $\mathrm{ml}$ portions) are shown above where (a) and (b) represent streptolydigin and actinomycin $\mathrm{D}$ treated cells, respectively. The level of radioativity in the control sample was $41,958 \mathrm{cts} / \mathrm{min}$ of ${ }^{3} \mathrm{H}$ and $128 \mathrm{cts} / \mathrm{min}$ of ${ }^{14} \mathrm{C}$ in the case of streptolydigin experiment; and $42,540 \mathrm{cts} / \mathrm{min}$ of ${ }^{3} \mathrm{H}$ and $492 \mathrm{cts} / \mathrm{min}$ of ${ }^{14} \mathrm{C}$ in the actinomycin $\mathrm{D}$ experiment. - - - Incorporated $\left[{ }^{3} \mathrm{H}\right]$ uridine; $--\mathrm{O}--\mathrm{O}-\cdots$, incorporated [14 $\mathrm{C}]$ thymine.

The above lysates were analyzed by centrifugation to equilibrium in $\mathrm{CsCl}$ gradients containing ethidium bromide in a manner similar to that of Fig. 2. (c) and (d), respectively, represent lysates of streptolydigin and actinomycin D-treated cells. The concentration of drug used is indicated in each panel. 


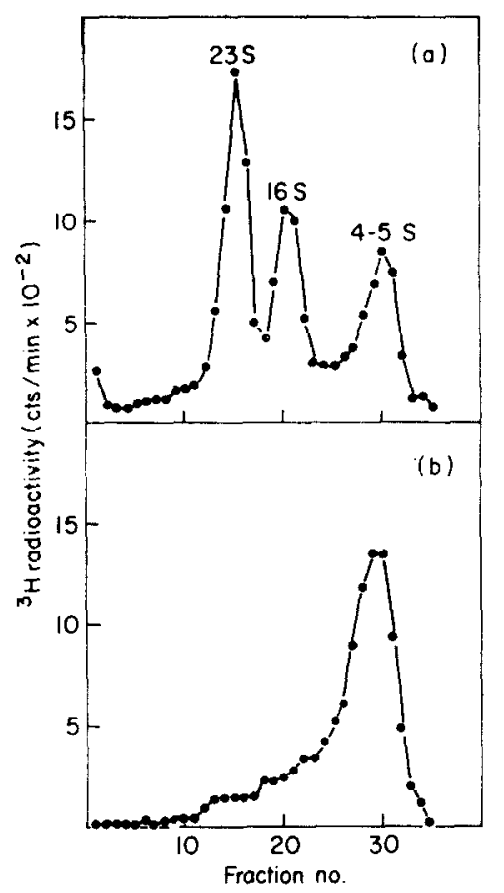

FIa. 4. Sedimentation analyses of RNA synthesized before and after treatment of cells with Cam. A culture of CR34 (Col E1) cells (44 ml) in M9-Casamino acids medium was grown to approx. $3 \times 10^{8}$ cells $/ \mathrm{ml}$. A $20-\mathrm{ml}$ portion of the cells was removed and labeled for $30 \mathrm{~min}$ with $0.2 \mathrm{mCi}$ of $\left[{ }^{3} \mathrm{H}\right]$ uridine and plunged into an ice bath. Cam $(175 \mu \mathrm{g} / \mathrm{ml})$ was added immediately to the remainder of the culture. After $3.5 \mathrm{~h}$ of exposure to the drug, another 20 -ml portion was removed and incubated similarly with $\left[{ }^{3} \mathrm{H}\right]$ uridine for $30 \mathrm{~min}$. RNA was extracted from each portion of cells, after whieh $0.2 \mathrm{ml}$ of each sample was centrifuged through 5 to $20 \%$ sucrose density gradients (from right to left) in a Beckman SW50.1 rotor $\left(15^{\circ} \mathrm{C}\right)$ at $48,000 \mathrm{revs} / \mathrm{min}$ for $120 \mathrm{~min}$. (a) Cells not treated with Cam; (b) treated cells.

to a level similar to that immediately before a Cam addition. After six and eight hours, the rate is decreased to 50 and $5 \%$, respectively, of the initial rate.

To determine the nature of the cellular RNA synthesized, a portion of cells was labeled with $\left[{ }^{3} \mathrm{H}\right]$ uridine before treatment while another portion was labeled following 3.5 hours of exposure to Cam. RNA was extracted and examined on sucrose density gradients. As shown in Figure 4, the RNA labeled before Cam treatment has a relatively normal pattern with three major peaks, which sediment at $23 \mathrm{~S}, 16 \mathrm{~S}$ and 4 to $5 \mathrm{~S}$ (corresponding to ribosomal and tRNA). After Cam treatment the pattern looks quite different, with a major decrease in the level of $23 \mathrm{~S}$ and $16 \mathrm{~S} \mathrm{RNA}$; while the slower sedimenting material appears not to be affected. A significant amount of the higher molecular weight material continues to be synthesized, but it appears rather heterogeneous. Thus, the inhibition of cellular RNA that is observed with increasing concentrations of antibiotics (see section (a) above) involves RNA that is relatively small (i.e. 4 to $5 \mathrm{~S}$ ).

\section{(c) Inhibition of protein synthesis}

In attempts to strengthen the view that inhibition of plasmid DNA synthesis by rifampicin is not the result of an indirect inhibition of a small amount of protein that 
escapes inhibition by Cam, several types of experiments were done. First, it was found that concentrations of Cam as high as $1000 \mu \mathrm{g} / \mathrm{ml}$ did not significantly alter the rate at which Col E1 DNA was synthesized. Second, we observed that puromycin $(1000 \mu \mathrm{g} / \mathrm{ml})$, tetracycline $(100 \mu \mathrm{g} / \mathrm{ml})$ and streptomycin $(200 \mu \mathrm{g} / \mathrm{ml})$ when present independently in the medium behaved similarly to Cam in allowing a selective continuation of Col El DNA synthesis, although in the case of tetracycline and streptomycin the rates of replication were only about $30 \%$ of that seen with Cam (as measured by observing the relative amounts of covalently closed circular DNA appearing in a dye-buoyant density gradient after treating uniformly labeled $\left(\left[{ }^{3} \mathrm{H}\right]\right.$ thymine) cells with drug for 4 to 5 hours). When tetracycline $(100 \mu \mathrm{g} / \mathrm{ml})$ was mixed with Cam $(200 \mu \mathrm{g} / \mathrm{ml})$, the amount of plasmid DNA synthesis was at approximately the same level as that seen when tetracycline alone was used. Similarly, when puromycin $(1000 \mu \mathrm{g} / \mathrm{ml})$ was mixed with Cam $(200 \mu \mathrm{g} / \mathrm{ml})$, the rate of replication was no different from that of cells treated with either puromycin or Cam alone.

In a third type of experiment, protein synthesis was examined directly by measuring the relative amounts of $\left[{ }^{3} \mathrm{H}\right] \mathrm{lcucine}$ incorporated into acid-precipitable material before Cam treatment of cells, as well as after a four-hour exposure to the drug. Incorporation was measured also in cells treated with rifampicin $(1 \mu \mathrm{g} / \mathrm{ml})$ during the last 0.5 hour of a four-hour treatment with Cam. It was found that inhibition was approximately $99 \%$ in cells treated with Cam, and no further inhibition was evident when rifampicin was also present. However, the background level of radioactivity in these experiments was relatively high and variable, making it difficult to assess accurately degrees of inhibition much greater than 98 to $99 \%$. Thus, if rifampicin did in fact have an additional inhibitory effect on protein synthesis, we probably would not detect it by this method.

\section{(d) Effect of rifampicin on plasmid replication in actively growing cells}

When actively growing cells were treated with a low level of rifampicin $(1 \mu \mathrm{g} / \mathrm{ml})$, which effectively inhibits Col El DNA synthesis in cells pretreated with Cam, we failed to observe any inhibition of either chromosomal or plasmid DNA synthesis. However, high concentrations of rifampicin produced a well-pronounced inhibition.

A culture of CR34 (Col E1) cells, grown for several generations in the presence of $\left[{ }^{14} \mathrm{C}\right]$ thymine to prelabel DNA, was divided into two equal portions and shifted (Clewell, 1972) to media containing $\left[{ }^{3} \mathrm{H}\right]$ thymine in place of $\left[{ }^{14} \mathrm{C}\right]$ thymine. One medium contained $250 \mu \mathrm{g}$ rifampicin $/ \mathrm{ml}$, while the other served as a control. When the control culture had undergone one generation of growth $(50 \mathrm{~min})$, both cultures were chilled rapidly in an ice bath. Crude lysates were prepared and samples were counted to determine the ratio of ${ }^{3} \mathrm{H}$ to ${ }^{14} \mathrm{C}$. Since plasmid DNA normally represents less than $2 \%$ of the total DNA (Clewell \& Helinski, 1970), this ratio reflects the extent of replication of chromosomal DNA following the medium shift. In the case of the control, this ratio should correspond to approximately one doubling of DNA. To determine the extent of replication of plasmid DNA, the lysates were centrifuged at $48,000 \mathrm{~g}$ for 20 minutes to remove most of the chromosomal DNA, and the supernatants (cleared lysates) were analyzed on sucrose density gradients, so that the ratio of ${ }^{3} \mathrm{H}$ to ${ }^{14} \mathrm{C}$ in plasmid DNA could be determined. Figure 5 shows the results of sucrose density analyses of the two lysates. Col El DNA is seen as a peak centered 


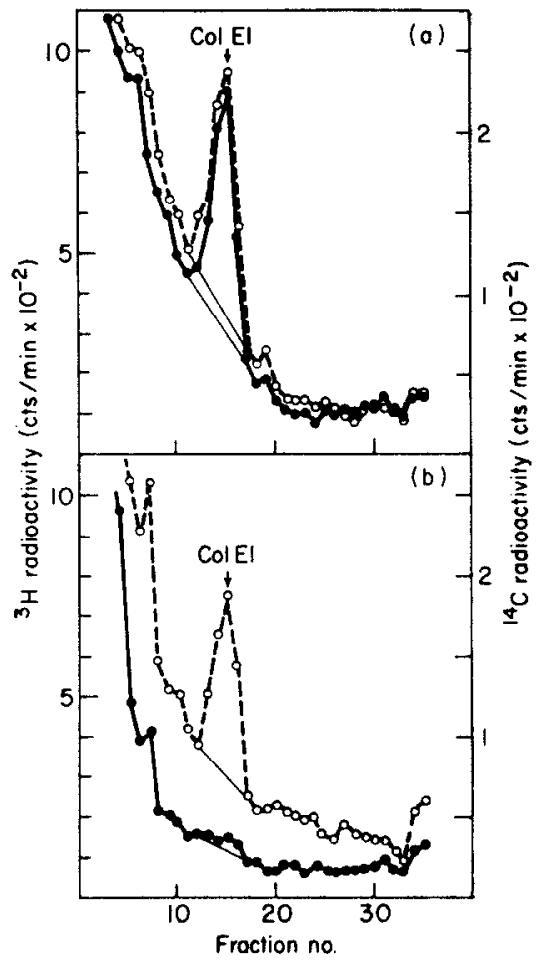

FIG. 5. Sedimentation analyses of lysates of cells with and without rifampicin treatment. A 40-ml culture of CR34 (Col El) cells grown for several generations in the presence of $\left[{ }^{14} \mathrm{C}\right]$ thymine $(2.0 \mu \mathrm{Ci} / 4.5 \mu \mathrm{g} / \mathrm{ml})$ was divided into 2 equal portions, pelleted and resuspended in 2 separate media (20 ml each) containing $\left[{ }^{3} \mathrm{H}\right]$ thymine $(25 \mu \mathrm{Ci} / 5 \cdot 2 \mu \mathrm{g} / \mathrm{ml})$ in place of the $\left.{ }^{14} \mathrm{C}\right]$ thymine. One medium contained $250 \mu \mathrm{g}$ rifampicin $/ \mathrm{ml}$ while the other served as a control. When the turbidity of the control culture had doubled $(50 \mathrm{~min})$, both cultures were chilled rapidly in an ice bath. Cleared lysates were prepared and sedimented through 5 to $20 \%$ sucrose density gradients (from right to left) in a Beckman SW50.1 rotor $\left(15^{\circ} \mathrm{C}\right)$ at $48,000 \mathrm{revs} / \mathrm{min}$ for $135 \mathrm{~min}$. (a) Cleared lysate of control cells not treated with rifampicin; (b) cleared lysate of cells treated with rifampicin. $-\mathrm{O}-,{ }^{3} \mathrm{H}$ radioactivity; -- $\mathrm{O}--\mathrm{O}--,{ }^{14} \mathrm{C}$ radioactivity.

around fraction 15. The incorporation of ${ }^{3} \mathrm{H}$ counts into Col El DNA in rifampicintreated cells is less than $5 \%$ that of the control whereas, on the basis of radioactivity in the crude lysates, chromosomal DNA synthesis in treated cells was $51 \%$ that of the control. Similar experiments involving samples of rifampicin-treated cells taken at one, two and four hours indicate that chromosomal DNA synthesis behaves as though current rounds of replication were being completed (within about $1 \mathrm{~h}$ ) prior to termination (Maaløe \& Hanawalt, 1961), whereas Col El synthesis appears to stop abruptly.

The requirement for a relatively high concentration of rifampicin to affect antively growing cells agrees with the data of others, indicating that the rifamycins are only weakly active against Gram negative bacteria for permeability reasons (Furesz et $a l .$, 1966). It is not clear why cells treated with Cam are sensitive to much lower concentrations of rifampicin than actively growing cells. Apparently, Cam treatment results in an alteration of the cell wall-membrane complex, resulting in an increase in the permeability of the drug. 


\section{Discussion}

In a previous report (Clewell et al., 1972) we suggested that the RNA involved in Col El replication may serve as a "primer". This notion is further strengthened by a recent report by Blair et al. (1972), which showed that a relatively large percentage of the Col El DNA molecules that accumulated during extensive treatment of cells with Cam were both alkali and RNase sensitive. By such treatment, the supercoils were observed to open to a relaxed configuration with an "opening" in only one strand. This was interpreted to mean that under these conditions (extensive Cam treatment) Col EI DNA contained a segment of RNA integrated in one strand. It was postulated that ribonucleotides normally were (after serving as a primer for DNA synthesis) removed and replaced by DNA, but that under the abnormal condition presented by the long incubation in the presence of Cam there is a failure in the "ribonucleotide-removal" (repair) mechanism. The replication process was required for generation of the RNase-sensitive circles, since rifampicin blocked their appearance.

We have shown here that in the presence of Cam the degree of inhibition of plasmid DNA synthesis by various concentrations of rifampicin is the same as the degree of inhibition of cellular RNA synthesis. In contrast, streptolydigin and actinomycin $D$ block Col E1 DNA synthesis only at concentrations at least 100-fold higher than that required to inhibit cellular RNA synthesis. The difference may be related to the fact that rifampicin blocks the initiation of RNA synthesis but does not inhibit growth of previously initiated RNA chains, whereas streptolydigin and actinomycin D interfere with strand elongation, respectively, by binding directly to RNA polymerase and to the DNA template (see Goldberg \& Friedman, 1971; Wehrli \& Staehelin, 1971). In the case of actinomycin $D$, the difference in sensitivity between cellular RNA synthesis and the synthesis of the putative primer RNA may reflect a small template size for the primer (Bleyman \& Woese, 1969) and/or a low template $\mathrm{G}+\mathrm{C}$ content (see Goldberg \& Friedman, 1971). In the case of streptolydigin, which slows down elongation by binding reversibly to RNA polymerase (Cassani et al., 1970; Heil \& Zillig, 1970), the lower sensitivity may be attributed either to a modification of the RNA polymerase involved in plasmid replication or to a specific compartmentalization of the transcription complex making streptolydigin binding difficult (compartmentalization would not necessarily be a barrier to rifampicin, since the latter could bind to the enzyme prior to binding of the enzyme to DNA).

In vitro studies on the coliphage M13 (Wickner et al., 1972) and $\phi$ XI74 (Schekman et al., 1972) systems strongly suggest that the synthesis of complementary DNA on the viral single-stranded circular template is dependent on the synthesis of a primer RNA. In the case of coliphage M13, rifampicin and streptolydigin block synthesis, while in the case of $\phi \times 174$, the synthesis of the RNA primer is resistant to these drugs (Schekman et al., 1972). Both systems, however, are sensitive to actinomycin $\mathrm{D}$ in vitro, a phenomenon possibly related to a hairpin double-helical region in the single-stranded templates where the RNA may be synthesized (Schekman et al., 1972). As in the case of $\phi X 174$, synthesis of RNA-primer of Okazaki fragments (Sugino et al., 1972) in E. coli is resistant to rifampicin. Thus, there must be more than one type of RNA polymerase activity in the cell. Whether or not these activities simply represent modified forms of a common core protein remains to be determined; however, it is conceivable that there are many modified forms of cellular RNA 
polymerase involved in many specific transcription events, one of which may involve a rifampicin-sensitive, streptolydigin-resistant activity involved in the synthesis of Col El primer RNA.

The studies involving actively growing cells demonstrated that rifampicin effectively inhibits the incorporation of radioactive thymine into Col El DNA, while allowing chromosomal DNA to complete the current round of replication. We view this as a blocking of the initiation of plasmid replication which appears as an immediate shut-off of the incorporation of label because plasmid replication, once started, is rapidly completed. That is, if a Col E1 DNA molecule replicates at the same DNA strand-elongation rate as that of chromosomal DNA, then it should take only a few seconds to complete a round of replication. It has, in fact, been determined that the strand elongation time is relatively short (Bazaral \& Helinski, 1970; Clewell, 1972).

This work was supported by U.S. Public Health research grants no. AI1031891 (National Institute of Allergy and Infectious Diseases) and no. DE02731 (National Institute of Dental Research), and an institutional research grant (no. IN40K) from the American Cancer Society to the University of Michigan. We wish to thank Sharon Schultz for her excellent technical assistance in parts of this work, Dr Shipman for various materials, and Drs Drach, Savageau and Cooper for helpful discussions. We also thank the Upjohn Company (Kalamazoo, Michigan) for their generous gift of streptolydigin.

\section{REFERENCES}

Bazaral, M. \& Helinski, D. R. (1968). J. Mol. Biol. 36, 185.

Bazaral, M. \& Helinski, D. R. (1970). Biochemistry, 9, 399.

Blair, D. G., Sherratt, D. J., Clewell, D. B. \& Helinski, D. R. (1972). Proc. Nat. Acad. Sci., Wash. 69, 2518.

Bleyman, M. \& Woese, C. (1969). Proc. Nat. Acad. Sci., Wash. 63, 532.

Cassani, G., Burgess, R. R. \& Goodman, H. M. (1970). Cold Spr. Harb. Symp. Quant. Biol. $35,59$.

Clewell, D. B. (1972). J. Bact. 110, 667.

Clewell, D. B. \& Helinski, D. R. (1969). Proc. Nat. Acad. Sci., Wash. 62, 1159.

Clewell, D. B. \& Helinski, D. R. (1970). Biochemistry, 9, 4428.

Clewell, D. B. \& Helinski, D. R. (1972). J. Bact. 110, 1135.

Clewell, D. B., Evenchik, B. \& Cranston, J. W. (1972). Nature New Biol. 237, 29.

Furesz, S., Arioli, V. \& Pallanza, R. (1966). Antimicrob. Ag. Chemother. 1965, 770.

Goldberg, I. H. \& Friedman, P. A. (1971). Ann. Rev. Biochem. 40, 775.

Heil, Z. \& Zillig, W. (1970). FEBS Letters, 11, 165.

Maaløe, O. \& Hanawalt, P. C. (1961). J. Mol. Biol. 3, 144.

Okada, T., Yanagisawa, K. \& Ryan, F. J. (1960). Nature, 188, 340.

Radloff, R., Bauer, W. \& Vinograd, J. (1967). Proc. Nat. Acad. Sci., Wash. 57, 1514.

Schekman, R., Wickner, W., Westergaard, O., Brutlag, D., Geider, K., Bertsch, T. T. \& Kornberg, A. (1972). Proc. Nat. Acad. Sci., Wash. 69, 2691.

Sugino, A., Hirose, S. \& Okazaki, R. (1972). Proc. Nat. Acad. Sci., Wash. 69, 1863.

Wehrli, W. \& Staehelin, M. (1971). Bact. Rev. 35, 290.

Wickner, W., Brutlag, D., Schekman, R. \& Kornberg, A. (1972). Proc. Nat. Acad. Sci., Wash. 69, 965. 